\title{
Does Financial Development Improve Income Inequality in Latin America?
}

\author{
Peter Mikek \\ Department of Economics, Wabash College, Indiana, USA
}

Received June 23, 2020; Revised July 22, 2020; Accepted August 25, 2020

Copyright $₫ 2020$ by authors, all rights reserved. Authors agree that this article remains permanently open access under the terms of the Creative Commons Attribution License 4.0 International License

\begin{abstract}
Latin America has experienced a trend of substantial reduction in inequality over last few decades. We investigate the effects of rapid development of financial sector on inequality in the region. In particular, we estimate a panel with country fixed effects based on a newly compiled dataset for time period of $1990-2017$. First, the main finding is that financial deepening has exacerbated income inequality on the continent during studied period indicating skewed distribution of benefits of this development across population. The reasons vary from relatively limited education (including low literacy rates), low collateral, demographic and geographic characteristics, and lack of tacit knowledge pertaining to access to financial services. Second, educational attainment seems to be a major contributor to lowering Gini coefficients. The countries in the region on average added about 3 years to education during this period and estimates suggest reduction of Gini coefficients of about 0.7 percentage points per additional year of schooling. Third, as expected, aggregate income level and its growth seem to significantly contribute to reduction of inequality in Latin America. In contrast, poverty rates are associated with worsening of income gap. Fourth, we found no evidence of a traditional Kuznetz curve for Latin America in this dataset. Finally, while exports seem to be neutral, FDI through raising high skill premia and taxes through low efficiency of public services aggravate inequality.
\end{abstract}

Keywords Income Inequality, Financial Deepening, Poverty, Income Distribution, Financial Development, Latin America

\section{Introduction}

Latin America is still a continent with high income inequalities deeply rooted in colonial heritage of extractive institutions (Acemoglu, Johnson and Robinson 2001) focused on export of agricultural products and raw materials. However, during recent decades most of the countries in the region experienced a substantial downward trend in income inequality (Gasparini and Lustig 2011), see Figure 1. Concurrently with this trend financial services have seen dramatic development along a number of dimensions. Thus, we asked what were the effects of changing financial landscape on income inequality?

The paper contributes to the existing literature along several dimensions. First, we investigate rather contrasting views on the role of financial sector found in literature. Second, we focus narrowly on Latin America while most studies of the kind are done based on a large group of very diverse developing countries. Third, we assemble a novel dataset from variety of sources covering the recent Great Recession and investigate educational attainment in the context of financial deepening. Fourth, we examine data for existence of traditional Kuznetz curve. Finally, we explicitly address FDI and exports for income inequality.

Our working hypotheses included significant effect of financial development on inequality. However, the direction of the effect was not determined a priori. Additionally, we expected to find confirmation of Kuznet's curve for the continent. Moreover, we hypothesized that education is narrowing the income gap, while international economic connections are exacerbating inequality.

Our results confirm an exacerbating effect of financial deepening on income gap and educational attainment reducing inequality in Latin America. We find no clear sign of Kuznetz curve and aggravating influence of poverty rates, taxes, and FDI on income distribution. Exports are not significant. 


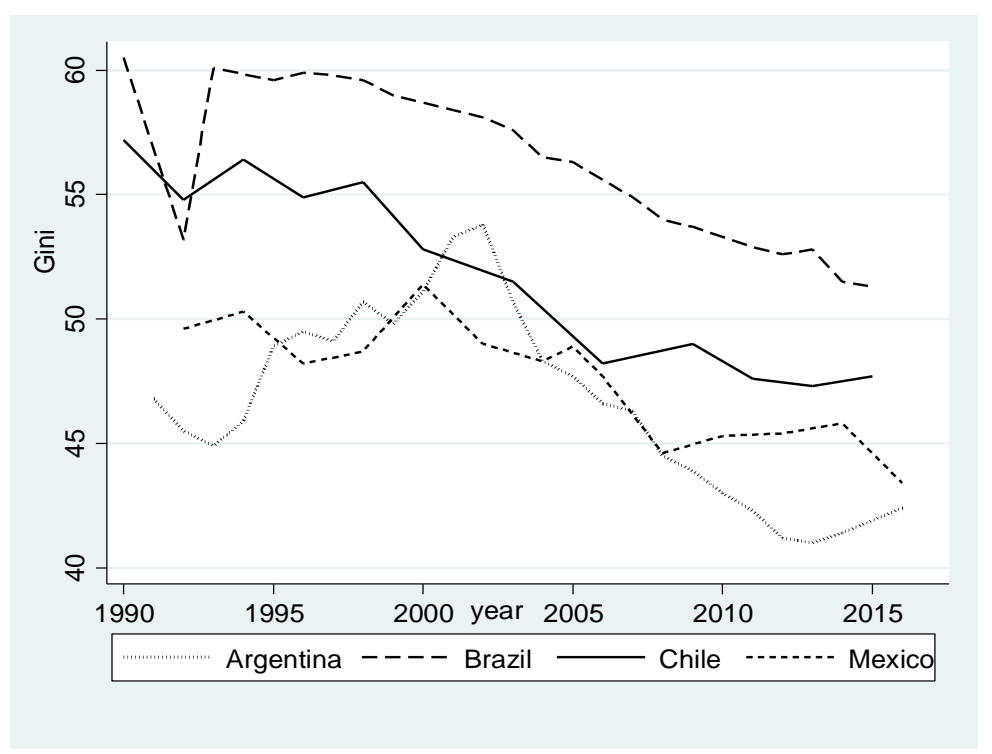

Figure 1. Gini coefficients for major Latin American countries

\section{Brief Literature Review}

Studies of the nexus of inequality and financial development report rather contrasting findings. Dabla-Noris et al. (2015) suggest that financial deepening is associated with worse inequality. Their explanation focuses on access to financial services. They suggest that small group of relatively wealthy individuals have much easier access to credit for variety of social and economic reasons. By the same token, Zhang and Naceur (2019) conclude that financial liberalization seems to have adverse effects on income distribution.

In contrast, there is a number of authors suggesting that financial deepening is associated with improvements in income gap. Papers report similar conclusion for a number of individual developing countries (Meyer Bittencourt 2006, Shahbaz and F. 2011) or datasets spanning many countries (Jauch and Watzka 2012). For example, Demirgut-Kunt and Levine(2009) claim that financial technology favorably affects growth rate and therefore reduces poverty rates. This improves income gap.

Similarly, there is no consensus about the effect of education on income distribution. Since education implies higher skill premiums it could be associated with worse income gap (O'Neill 1995). However, most studies do suggest that educational attainment tends to be associated with better inequality outcomes (De Gregorio and Lee 2002, Abdullah, et al. 2015, Mikek and Simmons 2019). As diverse educational achievements tend to be associated with different skill levels, dispersion of education outcomes, not just levels, is relevant. Therefore, a number of studies pay special attention to dispersion of education (De Gregorio and Lee 2002, Coady and Dizioli 2018) and some even include education Gini coefficients into their analysis (Dabla-Noris, et al. 2015). Tsounta and Ouseke (2014) conclude that educational attainment is one of the major contributors to decreasing inequality in Latin America. The results of Dabla-Noris (2015) and Mikek and Simmons (2019) seem to suggest the same conclusion. Along with these, Sylwester (2004) and De Gregorio and Lee (2002) propose that countries could reduce the income gap by devoting more substantial resources to further develop human capital of their residents.

There is a widely shared view that poverty is closely associated with worse income distribution outcomes. Ravallion (2001), Nijhawan and Dubas (2006) and others report rather robust conclusion that poverty worsens income gap through its effect on potential earning capacity. This is due to health (nutrition), access to infrastructure, and other barriers faced by poor population. In this way, it considerably contributes to inequality.

Similarly, the relevance of both the level and growth of aggregate income for inequality enjoys a wide agreement in literature. As the level of output increases income gap is reported to be decreasing in wide variety of countries (Beck, Demirguc-Kunt and Levine 2007, Jauch and Watzka 2012, Gasparini and Lustig 2011, Tsounta and Ouseke 2014, Mikek and Carter 2017). Countries with higher GDP per capita are able to provide better access to infrastructure, education, health services, etc. for the lower part of the income spectrum thereby closing the income disparities to some degree.

Ever since the seminal paper of Kuznetz (1955), researcher investigate if the inequality might follow the Kuznetz curve: increasing as income increases to a certain point and then start dropping as countries become ever richer in an inverted U curve pattern (Tsounta and Ouseke 2014, Jauch and Watzka 2012). Growth of output, however, could potentially have negative effects on income distribution (Dabla-Noris, et al. 2015) due to technological changes that favor skilled labor.

There is no agreement in existing studies about the effect 
of international trade on inequality. While some claim that it reduces income gap (Jaumotte, Lall and Papageorgiou 2013) others point out that it facilitates transfer of more advanced technologies and therefore exacerbates income gap through higher skill premium (Dabla-Noris, et al. 2015). Furthermore, there are at least two mechanisms through which FDI affects income distribution. On one hand, FDI is vehicle for transferring more advanced technologies and therefore worsens inequality through skill-biased technological development (Jaumotte, Lall and Papageorgiou 2013, Mikek and Carter 2017). In contrast, some consider effect of FDI on growth and find inequality reducing effect (Tsounta and Ouseke 2014).

Finally, many authors study and propose suggestions for public policies that would help reducing income gap (Tsounta and Ouseke 2014, Dabla-Noris, et al. 2015, Demirgiuc-Kunt and Levine 2009, De Gregorio and Lee 2002).

\section{Methodology}

Data span almost three decades from 1990 to 2017 and cover 16 major Latin American countries: Argentina, Bolivia, Brazil, Chile, Colombia, Costa Rica, Dominican Republic, Ecuador, Guatemala, Honduras, Mexico, Panama, Paraguay, Peru El Salvador, and Uruguay. Data from World Development Indicators (2019) were supplemented with International Financial Statistics (IFS 2019), FRED (2018), and Human Development Indicators (HDI 2019). We measure inequality as an income based Gini coefficient. We focus on financial development and narrowly specify it as financial deepening that is defined as a share of private credit in GDP.

We estimated an unbalance fixed effect panel with dummies for each country as follows:

$$
\begin{aligned}
& \text { Gini }_{\text {it }}=\mathrm{b}_{0}+\mathrm{b}_{1} \mathrm{FD}_{\mathrm{it}}+\mathrm{b}_{2} \mathrm{SCH}_{\mathrm{it}}+\mathrm{b}_{3} \mathrm{PVRT}_{\mathrm{it}}+\mathrm{b}_{4} \mathrm{GNIPC}_{\mathrm{it}}+ \\
& \mathrm{b}_{5} \mathrm{GNIPC}_{\mathrm{it}}{ }^{2}+\mathrm{b}_{6} \Delta \mathrm{GDP}_{\mathrm{it}}+\mathrm{b}_{7} \mathrm{Z}_{\mathrm{it}}+\mathrm{u}_{\mathrm{i}}+\mathrm{e}_{\mathrm{it}}
\end{aligned}
$$

where $\mathrm{i}=1, \ldots, \mathrm{N}=16$, for country and $\mathrm{t}=$ $1, \ldots, \mathrm{T}=28$, for year.

$\mathrm{e}_{\mathrm{it}}$ is the white noise error term, $\mathrm{u}_{\mathrm{i}}$ is country fixed effect, and $b_{0 i}$ is a constant, GNIPC is gross national income per capita, SCH stands for schooling, FD measures financial deepening, $\triangle$ GDP stands for growth rate of GDP, PVRT for the share of people in poverty. We follow the World
Bank considering a share of those with less than $\$ 2$ per day to be poor. $\mathrm{Z}$ is a vector of other standard control variables (such as exports, FDI, inflation, taxes, etc.). Exports are measured as a growth rate, and FDI is a share of FDI in GDP. Similarly, taxes are expressed as a share of tax revenues in GDP.

To determine whether to use a fixed effects or random effects panel we performed the Hausman test. For most models, the test indicates that we can reject the $\mathrm{H}_{0}{ }^{\circ}\left(\mathrm{B}_{1}-\mathrm{B}_{2}\right)$ is not systematic at $5 \%$ significance level (see details in appendix below in Table A3). This, therefore, favors application of the fixed effects over the random effects panel.

While our primary interest will be captured by the coefficient on financial deepening, we will also check for the existence of Kuznetz curve by including the square of aggregate income. Given conflicting claims in the literature surveyed above, it is not clear what to expect for the sign of $\mathrm{b}_{1}$ coefficient. By the same token, studies report contrasting results for $b_{5}$. However, most papers do suggest that the higher level of income per capita is associated with lower inequality. Thus, we expect negative $b_{4}$. As reported above, we find contrasting results for some of the control variables, such as export and FDI, in literature. However, we expect to see a negative $b_{2}$ that would indicate that the educational attainment contributes to reduction of inequality

\section{Results and Discussion}

After a brief comment on overall model fit, we will first present our initial estimates focusing on the variables of our primary interest in Table 1, then we will expand on those and include exports, FDI and taxes in Table 2 below.

Overall, the results indicate satisfactory determination coefficients of about 0.6 within groups. F-tests reject the null of no systematic relationship between Gini coefficients and regressors at high significance for each model. We investigated the possible effects of multicollinearity through the correlations among regressors (Table A1 in appendix) and calculated Variance Inflation Factors (VIF). While few correlation coefficients were significant, we found that VIF numbers, that are given as illustration for two models considered in Table A2, to be rather modest, indicating that multicollinearity is not a serious problem in this dataset. 


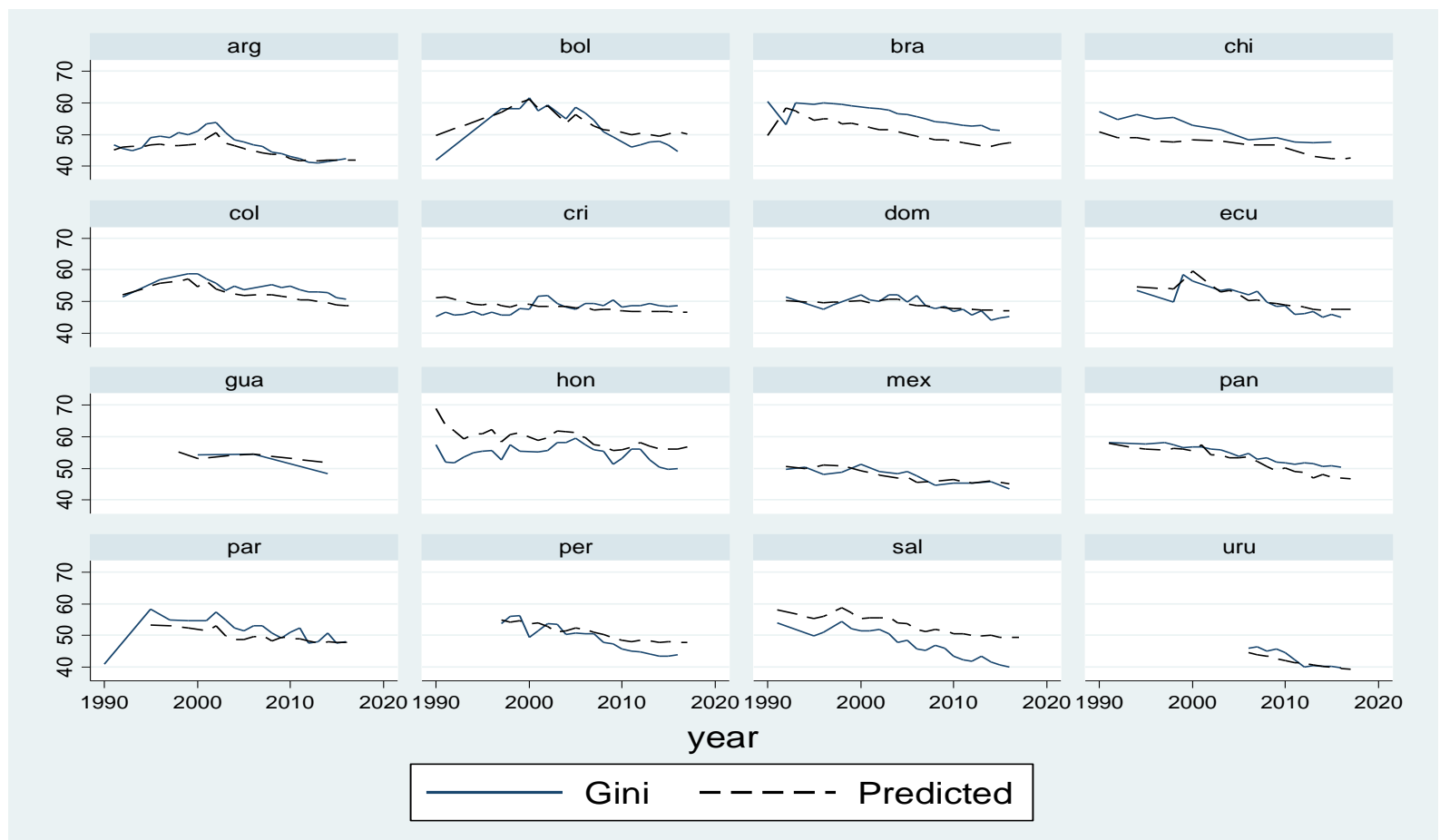

The names are the first three letters of the country name, with exception of "cri” that stands for Costa Rica and "sal” that stands for El Salvador. The predicted values here are based on model (7) in Table 2 below.

Figure 2. Predicted and actual values

Figure 2 presents actual and predicted values, based on model (3) in Table 1 below. It shows quite a good fit across most countries, except for El Salvador and Brazil. While we present only one set of graphs, the others were comparable, with minor variations. Despite the fact that the available data for Guatemala and Uruguay was relatively short, the model captures dynamics even for these two countries relatively well. Our modeling approach is further validated by a large share of variance due to individual fixed effects $u_{i}$ as estimated in rho's given in both tables below. It is roughly between 66 and $81 \%$.

Table 1 below reports the results of our initial estimates. The benchmark model is given in column (1) of the table. The coefficient on educational attainment is negative and highly significant, suggesting a drop of about 2 percentage points in inequality associated with additional year in mean years of schooling (De Gregorio and Lee 2002, Mikek and Simmons 2019). Given that the region experienced an increase of a bit more than 3 years in mean years of schooling over the observed period, this is a sizable contribution to reduction of Gini coefficients in the region.

Table 1 (and Table 2) also shows that the level of output and its growth rate correlate with lower income gap, as was expected given the surveyed literature above (Ravallion 2001). Inflation rate affects income distribution in several ways. It seems that the one most prominent here is the redistribution of wealth from relatively rich lenders to relatively poorer borrowers (Zhang and Naceur 2019).

Overall, we found no evidence for existence of the standard Kuznetz curve (Kuznetz 1955) as coefficients on squared output term are not significant. We notice a significant one in column 3 , however, the coefficient there is absolutely miniscule (of order $10^{-8}$ ).

Additionally, inclusion of poverty rate in column (3) reduces the effect of education, which, however, remains substantial and significant. 
Table 1. Initial estimates (dependent variable Gini coefficient)

\begin{tabular}{|c|c|c|c|}
\hline & (1) & (2) & (3) \\
\hline \multirow[t]{2}{*}{ FD } & & $0.063^{* *}$ & $0.059^{* *}$ \\
\hline & & $(0.000)$ & $(0.000)$ \\
\hline \multirow[t]{2}{*}{$\mathrm{SCH}$} & $-2.027^{* *}$ & $-2.333^{* *}$ & $-0.774^{*}$ \\
\hline & $(0.000)$ & $(0.000)$ & $(0.012)$ \\
\hline \multirow[t]{2}{*}{ PVRT } & & & $0.464^{* *}$ \\
\hline & & & $(0.000)$ \\
\hline \multirow[t]{2}{*}{ GNIPC } & $-0.001^{+}$ & $-0.001^{*}$ & 0.001 \\
\hline & $(0.086)$ & $(0.038)$ & $(0.154)$ \\
\hline \multirow[t]{2}{*}{ GNIPC2 } & 0.000 & 0.000 & $-0.000^{* *}$ \\
\hline & $(0.620)$ & $(0.658)$ & $(0.004)$ \\
\hline \multirow[t]{2}{*}{$\Delta \mathrm{GDP}$} & $-0.132^{*}$ & $-0.108^{*}$ & 0.013 \\
\hline & $(0.014)$ & $(0.039)$ & $(0.766)$ \\
\hline \multirow[t]{2}{*}{ Inflat. } & -0.001 & $-0.003^{* *}$ & $-0.003^{* *}$ \\
\hline & $(0.105)$ & $(0.002)$ & $(0.000)$ \\
\hline \multirow[t]{2}{*}{ _cons } & $71.301^{* *}$ & $72.309^{* *}$ & $49.201^{* *}$ \\
\hline & $(0.000)$ & $(0.000)$ & $(0.000)$ \\
\hline$N$ & 297 & 297 & 297 \\
\hline$F$ & 41.63 & 39.39 & 65.84 \\
\hline$P$-val & $(0.000)$ & $(0.000)$ & $(0.000)$ \\
\hline Rho (var. due to $u_{i}$ ) & 0.767 & 0.794 & 0.659 \\
\hline$R^{2}$ within & 0.430 & 0.462 & 0.627 \\
\hline Between & 0.150 & 0.240 & 0.492 \\
\hline overall & 0.185 & 0.236 & 0.500 \\
\hline AIC & 1411 & 1396 & 1289 \\
\hline
\end{tabular}

$p$-val. in parentheses, $+\mathrm{p}<0.1,{ }^{*} \mathrm{p}<0.05,{ }^{* *} \mathrm{p}<0.01$

AIC is Akaike Information criterion

Nevertheless, the most important result in Table 1 is the inclusion of financial deepening into the benchmark model. Results suggest that there is a significant effect of financial deepening on income distribution. In particular, an increase of the share of credit in GDP by a percentage point is associated with higher Gini coefficient by about 0.04-0.06 percentage points. As shown in tables 1 and 2, this result is robust across all estimated models. Consistently, further financial deepening correlates with worse income gap.

There may be different explanations for the phenomena, however, most likely seems to suggest that the benefits of expansion in credit are concentrated in relatively small group (or groups) of people across Latin America (Dabla-Noris, et al. 2015). People from the bottom part of the income spectrum face variety of obstacles preventing them to benefit from financial deepening. Low education levels (with low literacy), poor health and nutrition, limited access to financial and other infrastructure, lack of adequate collateral and necessary tacit knowledge, and administrative barriers all likely contribute to limited benefits of credit expansion for relatively poor (Demirgiuc-Kunt and Levine 2009, Dabla-Noris, et al. 2015). These barriers don't limit only access to the financial services but also more broadly economic opportunities for less fortunate. This additionally limits the likelihood of obtaining credit. Moreover, there are large discrepancies between rural and urban Latin America that are particularly pertinent to financial development and access to financial services. 
Table 2. Beyond initial results (dependent variable: Gini coefficient)

\begin{tabular}{|c|c|c|c|c|}
\hline & (4) & (5) & (6) & (7) \\
\hline \multirow[t]{2}{*}{ FD } & $0.058^{* * *}$ & $0.044^{* *}$ & $0.044^{* *}$ & $0.058^{* *}$ \\
\hline & $(0.000)$ & $(0.001)$ & (0.001) & $(0.000)$ \\
\hline \multirow[t]{2}{*}{$\mathrm{SCH}$} & $-0.656^{*}$ & $-0.737^{*}$ & $-0.742^{*}$ & $-0.715^{+}$ \\
\hline & $(0.031)$ & (0.013) & $(0.012)$ & $(0.075)$ \\
\hline \multirow[t]{2}{*}{ GNIPC } & $-0.001^{* *}$ & $-0.001^{* *}$ & $-0.001^{* *}$ & $-0.001^{* *}$ \\
\hline & $(0.000)$ & $(0.000)$ & $(0.000)$ & $(0.001)$ \\
\hline \multirow[t]{2}{*}{ Inflat. } & $-0.003^{* *}$ & $-0.003^{* *}$ & $-0.003^{* *}$ & $-0.003^{* *}$ \\
\hline & $(0.000)$ & $(0.000)$ & $(0.000)$ & $(0.000)$ \\
\hline \multirow[t]{2}{*}{ PVRT } & $0.417^{* *}$ & $0.422^{* *}$ & $0.421^{* *}$ & $0.519^{* *}$ \\
\hline & $(0.000)$ & $(0.000)$ & $(0.000)$ & $(0.000)$ \\
\hline \multirow[t]{2}{*}{ Export } & 0.010 & & 0.009 & \\
\hline & $(0.580)$ & & $(0.621)$ & \\
\hline \multirow[t]{2}{*}{ FDI } & & $0.296^{* *}$ & $0.295^{* *}$ & \\
\hline & & $(0.000)$ & $(0.000)$ & \\
\hline \multirow[t]{2}{*}{ Tax } & & & & $0.205^{+}$ \\
\hline & & & & $(0.062)$ \\
\hline \multirow[t]{2}{*}{ _cons } & $53.493^{* *}$ & $54.764^{* *}$ & $54.688^{* *}$ & $51.308^{* *}$ \\
\hline & $(0.000)$ & $(0.000)$ & $(0.000)$ & $(0.000)$ \\
\hline$N$ & 297 & 297 & 297 & 214 \\
\hline $\mathrm{F}$ & 73.36 & 80.48 & 68.83 & 48.97 \\
\hline$P$-val & $(0.000)$ & $(0.000)$ & $(0.000)$ & $(0.000)$ \\
\hline Rho (var. due to $u_{i}$ ) & 0.753 & 0.806 & 0.803 & 0.806 \\
\hline$R^{2}$ within & 0.615 & 0.637 & 0.637 & 0.602 \\
\hline Between & 0.380 & 0.3317 & 0.334 & 0.446 \\
\hline Overall & 0.3978 & 0.306 & 0.363 & 0.381 \\
\hline AIC & 1296 & 1279 & 1281 & 927 \\
\hline
\end{tabular}

p-val. in parentheses, $+\mathrm{p}<0.1,{ }^{*} \mathrm{p}<0.05,{ }^{* *} \mathrm{p}<0.01$

AIC is Akaike information criterion

In table 2 we present results of estimation beyond the initial ones. At the outset, note that financial development and educational attainment for all four estimated models remain highly significant with the same signs as in table 1 (inequality reducing schooling and inequality increasing financial deepening). Similarly, coefficients on inflation rate, output level and poverty rate across all estimated models remain significant and with consistent signs (as seen in Table 1).

Including exports and FDI in models (4) and (6) render an improvement in the Akaike information criterion, mirroring the importance of international economic relations of the countries in the region. Concerning export, we find no statistically significant correlation between international trade (growth of export) and inequality in the region. The results are consistent with some previous studies (Dabla-Noris, et al. 2015).

FDI estimates are given in columns (5) and (6). And increase of a percentage point in FDI, as a share in GDP, is consistently associated with an increase in Gini coefficients in the region for about a third of a percentage point. Such results concur with findings of Cornia (2012) and te Velde (2003). The coefficients indicate that FDI in rapidly growing Latin America has most likely been skill-biased favoring high skilled labor at the expense of those with lower level skills (Dabla-Noris, et al. 2015). This calls for further development of public policy programs that will stimulate accumulation of human capital in the region. An example of such program is Mexico's Progresa/Opportunidades /Prospera, for which Lustig, Lopez-Calva, and Ortiz-Juarez (2013) suggest to have contributed as much as staggering $18 \%$ to the reduction Gini coefficient.

Our results are in stark contrast with claims of Tsounta and Ouseke (2014) that it was FDI that considerably contributed to reduction of income inequality across Latin America. However, we suspect that a richer model that the one they employed may have rendered different results.

Finally, the literature (Tsounta and Ouseke 2014, Dabla-Noris, et al. 2015, Mikek and Carter 2017) regularly 
includes tax revenues as an indicator of redistributive policies by the governments. Higher income taxes are most likely collected from those that can actually pay them on the upper part of the income distribution. Thus, they lower the incomes of wealthy. In this way, they diminish income disparities. Additionally (but by no means guaranteed), the government may use some of these funds to finance social programs that are most likely to benefit those from the lower part of the income spectrum. Two examples of such programs are Progresa/Opportunidades/Prospera in Mexico and Bolsa Familia and Beneficio de Prestacao Continuada in Brazil (Ferreira, et al. 2011). The results seem to suggest that tax revenues actually increase income inequality indicating relatively low redistributive effect. This corresponds to findings of Ferreira et al. (2011) suggest that the program for Brazil was not effective as the prices of food items grew over the period of the program.

\section{Conclusions}

We studied effects of financial deepening on income inequality and found that financial deepening exacerbated the inequality in Latin America over the investigated period. This indicates skewed distribution of benefits of financial development and is likely due to easier access to financial services for only a small share of population.
The benefits are not shared across a broad spectrum of population due to a variety of factors, including relatively limited education (including low literacy rates), low collateral, demographic and geographic distribution of population, and lack of tacit knowledge pertaining to access to financial services.

In contrast, however, our results indicate that educational attainment was the major contributor to improving Gini coefficients on the continent. Mean years of schooling increased on average by about 3 years over the studied period. Additional education time is likely to contribute to skill set of all workers (particularly to those from low income backgrounds) and therefore it improves skill premium of new entrants to the labor force and in this way reduces inequality.

Additionally, we found no clear evidence of the traditional Kuznetz curve in Latin America. Finally, FDI and tax revenues worsen inequality while exports are not statistically significant. FDI in the region is a vehicle for transfer of advanced technologies from abroad and, thus, requires highly skilled labor. Workers that are employed and trained in sectors benefiting from FDI earn higher skill premium widening the inequality gap. In a region with high corruption rates and low efficiency of public services taxes worsen the income distribution due to very low redistributive effect.

\section{Appendix}

Table A1. Correlation Matrix

\begin{tabular}{|c|c|c|c|c|c|c|c|c|c|}
\hline & FD & SCH & PVRT & GDNIPC & $\Delta$ GDP & Infl & EXP & FDI & Tax \\
\hline FD & 1 & & & & & & & & \\
\hline SCH & $0.33^{*}$ & 1 & & & & & & & \\
\hline PVRT & -0.01 & $-067^{*}$ & 1 & & & & & & \\
\hline GNIPC & $0.28^{*}$ & $0.59^{*}$ & $-0.61^{*}$ & 1 & & & & & \\
\hline$\Delta$ GDP & 0.01 & 0.09 & -0.16 & -0.03 & 1 & & & & \\
\hline Infl & 0.01 & -0.10 & 0.16 & -0.01 & $-0.17^{*}$ & 1 & & & \\
\hline EXP & -0.09 & -0.06 & 0.05 & -0.04 & $0.39^{*}$ & -0.08 & 1 & & \\
\hline FDI & $0.57^{*}$ & $0.46^{*}$ & $-0.19 *$ & $0.31^{*}$ & 0.20 & -0.11 & -0.07 & 1 & \\
\hline Tax & $0.42^{*}$ & $0.38^{*}$ & -0.11 & $0.37^{*}$ & 0.10 & -0.12 & -0.07 & $0.42^{*}$ & 1 \\
\hline
\end{tabular}

* Indicates significant at $1 \%$ significance level 
Table A2. Variance Inflation Factors

\begin{tabular}{|c|c|c|}
\hline Variable & VIF Model (7) & VIF Model (2)* \\
\hline PVRT & 2.34 & 1.5 \\
\hline GNIPC & 1.84 & 1.64 \\
\hline SCH & 2.24 & 1.04 \\
\hline$\Delta$ GDP & - & 1.15 \\
\hline Infl & 1.2 & 1.08 \\
\hline FD & 1.57 & - \\
\hline FDI & 1.46 & - \\
\hline EXP & 1.01 & $\mathbf{1 . 2 8}$ \\
\hline Mean VIF & $\mathbf{1 . 7}$ & \\
\hline
\end{tabular}

* Excluding the squared term

Table A3. Hausman test

\begin{tabular}{|c|c|c|c|c|c|c|c|}
\hline Model & $(1)$ & $(2)$ & $(3)$ & $(4)$ & (5) & (6) & (7) \\
\hline Chi $^{2}$ & 16.460 & 69.730 & 6.830 & 16.250 & 36.240 & 27.600 & 7.160 \\
\hline p-value & 0.003 & 0.000 & 0.337 & 0.013 & 0.000 & 0.000 & 0.306 \\
\hline & \multicolumn{7}{|c|}{$\mathrm{H}_{0}$ : NO systematic difference in coefficients (random effects) } \\
\hline
\end{tabular}

\section{REFERENCES}

[1] Abdullah, A., Doucouliagos, H., Manning, E., \& a. (2015). Does Education Reduce Income Inequality? A Meta Regression Analysis. Journal of Economic Surveys, 301-316.

[2] Acemoglu, D., Johnson, S., \& Robinson, J. (2001). The Collonial Origins of Comparative Development: An Empirical Investigation. American Economic Review, 91(5), 1369-1401.

[3] Beck, T., Demirguc-Kunt, A., \& Levine, R. (2007). Finance, poverty and income inequality: cross-country evidence. NBER Working Paper Seris 10979.

[4] Coady, D., \& Dizioli, A. (2018). Income Inequality and Education Revisited: Persistence, Endogeneity and Heterogeneity. Applied Economics.

[5] Cornia, G. A. (2012). Inequality trends and their determinants: Latin America over 1990 - 2010. WIDER Working Paper, No. 2012/09.

[6] Dabla-Noris, E., Kochhar, K., Sphaphiphat, N., Ricka, F., \& Tsounta, E. (2015). Couses and Consequences of Income Inequality: A Global Perspective. IMF Staff Discussion Note $15 / 13$

[7] De Gregorio, J., \& Lee, J.-W. (2002). Education and Income Inequality: New Evidence From Cross - Country Data. The Review of Income and Wealth, 395-416.

[8] Demirgiuc-Kunt, A., \& Levine, R. (2009). Finance and Inequality: Theory and Evidence. World Bank Policy Research Working Paper 4967.

[9] Education Statistics - All Indicators. (2019, June 13). Retrieved August 2, 2019, from The World Bank: https://databank.worldbank.org/source/education-statistics$\wedge$-all-indicators

[10] Ferreira, F., Fruttero, A., Leite, P., \& Luccetti, L. (2011). Raising Food Prices and Household Welfare: Evidence from Brazil 2008. Worl Bank Policy Research Working Paper 5652. Washington, D.C.: World Bank.

[11] FRED, S. L. (2018, March 26). Inflation, consumer prices for Argentina. Retrieved August 5, 2019, from Economic Research Federal Reserve Bank of St. Louis: https://fred.stlouisfed.org/series/FPCPITOTLZGARG

[12] Gasparini, L., \& Lustig, N. (2011). The Rise and Fall of Income Inequality in Latin America. Society for the Study of Economic Inequality Working Paper no. 2011-213.

[13] HDI. (2019, January 29). Human Development Index. Retrieved August 2, 2019, from United Nations Development Programme: http://hdr.undp.org/en/data

[14] IFS. (2019). IFS-International Monetary Fund. Retrieved 08 02, 2019, from http://data.imf.org/?sk=4C514D48-B6BA-4 9ED-8AB9-52B0C1A0179B

[15] Jauch, S., \& Watzka, S. (2012). Financial Development and Income Inequality: A Panel Data Approach. CESifo Working Papers no. 3687.

[16] Jaumotte, F., Lall, S., \& Papageorgiou, C. (2013). Rising Income Inequality: Technology, or Trade and Financial Globalization? IMF Economic Review, 61(2), 271-309.

[17] Kuznetz, S. (1955). Economic Growth and Income Inequality. The American Economic Review, 45, 1-28.

[18] Lustig, N., Lopez-Calva, L. F., \& Ortiz-Juarez, E. (2013). Declining Inequality in Latin America in the 2000s: The Case of Argentina, Brazil, and Mexico. World Development, 44, 129-141.

[19] Meyer Bittencourt, F. (2006). Financial Development and 
Inequality: Brazil. SSRN Electronic Journal 12/2006.

[20] Mikek, P., \& Carter, A. (2017). Income Inequality In Latin America and Eastern EU through the Great Recession: An Ordered Probit Analysis. Advances in Economics and Business, 5(10), 539-549.

[21] Mikek, P., \& Simmons, M. (2019). Crisis, Education, and Income Inequality in Latin America and Asia: A Panel Approach. Manuscript.

[22] Nijhawan, I., \& Dubas, K. (2006). A reassessment of the relationship between income inequality and poverty. Journal of Economics and Economic Education Research, 7, 103-115.

[23] O'Neill, D. (1995). Education and Income Growth: Implications for Cross-Country Inequality. Journal of Political Economy, 103(6), 1289-1301.

[24] Ravallion, M. (2001). Growth, Inequality, and Poverty: Look Beyond Averages. World Development, 29, 1803-1815.
[25] Shahbaz, M., \& F., I. (2011). Financial development and income inequality in Pakistan: An application of ARDL approach. Journal of economic development, 36, 35-53.

[26] Sylwester, K. (2004). A note of geography, institutions, and income inequality. Economic Letters, 85, 235-240.

[27] te Velde, D. W. (2003). Foreign direct investment and income inequality in Latin America: Experiences and policy implications. Documento de Trabajo, No. 04/03.

[28] Tsounta, E., \& Ouseke, A. (2014). What is Behind Latin America's Declining Income Inequality? IMF Working Paper no 14/124.

[29] World Development Indicators. (2019, July 10). Retrieved August 5, 2019, from The World Bank: https://databank.worldbank.org/source/world-developmentindicators

[30] Zhang, R., \& Ben, N. S. (2019). Financial Development, Inequality and Poverty: Some International Evidence. International Review of Economics \& Finance, 61, 1-16. 